\title{
The Flexner report: 100 years later
}

\author{
Douglas Page, Adrian Baranchuk
}

Department of Cardiology, Kingston General Hospital, Queen’s University, Kingston, Ontario, Canada

Correspondence: Adrian Baranchuk, Department of Cardiology, Kingston General Hospital, Queen’s University, Kingston, Canada, Email: barancha@kgh.kari.net

Accepted: October 12, 2010

One hundred years ago, medical education in the US and Canada was very different than it is today. There was little standardization regulating how medical education was delivered, and there was wide variation in the aptitude of practicing physicians. Though some medical education was delivered by the universities, many non-university affiliated schools still existed. Besides scientific medicine, homeopathic, osteopathic, chiropractic, botanical, eclectic, and physiomedical medicine were all taught and practiced by different medical doctors at that time. In addition, there were far more medical schools at the beginning of the $20^{\text {th }}$ century than there are today, and they varied greatly in the quality of their teaching staff and their laboratory and clinical facilities. ${ }^{1}$ There was little done to try and regulate the number of practicing doctors at the time, leading to an oversupply of physicians. This variety of educational methods, lack of entrance requirements and licensing examinations, as well as little insight regarding optimal numbers of practicing physicians resulted in an abundance of unreliable medicine in the early 1900 's. ${ }^{2}$

The Flexner report, published in 1910, was written as one of North America's earliest large scale attempts to standardize medical education. ${ }^{2}$ In 1908, the Carnegie Foundation appointed Abraham Flexner to undertake a survey of medical education across the US and Canada in order to evaluate all medical schools in existence at that time. Flexner was an American educator with degrees from John Hopkins and Harvard Universities. Though he did not have a degree in medicine, Flexner was a prime candidate for the job because of his ideals regarding the delivery of higher education. Flexner visited 155 schools in 18 months to evaluate their laboratory and clinical facilities, admissions requirements, student fees, endowment funds, and quality of teaching. ${ }^{3,4} \mathrm{He}$ also recorded ratios of practicing physicians for different provinces and states. Interestingly, though Flexner reported a surplus of physicians at that time, the ratio of physicians per population is almost double today what it was in 1908 (Table 1). The way medicine is practiced has evolved greatly in the last 100 years, and the science of predicting physician supply today is more complex than just numbers alone.
Following Flexner's recommendations, accreditation programs and a shift in resources led to the closure of many of the medical schools in existence at that time. Medical training became much more centralized, with smaller rural schools closing down as resources were concentrated in larger Universities that had better training facilities. Proprietary schools were terminated, and medical education was delivered with the philosophy that basic sciences and clinical experience were paramount to producing effective physicians. ${ }^{2}$

These changes effectively homogenized medical education across the US and Canada. High admission standards, long and intense medical training, and ubiquitous licensing examinations led to a relatively consistent quality of medicine delivered in the US and Canada today. However, there have been drawbacks to the changes caused by this report as well. Closure of smaller rural training facilities and higher costs of medical education has made receiving a medical degree less accessible to minority groups, people with lower socioeconomic status, and students from rural areas. $^{5-7}$

Table 1.Comparison of historical data from the Flexner report in 2008 to current data in 2009 looking at physician resources in Canada

\begin{tabular}{lll}
\hline & $1908^{\dagger}$ & $\mathbf{2 0 0 9}$ \\
\hline Population in Canada & $6,945,228$ & $33,212,696$ \\
Number of Physicians & 6,736 & 66,992 \\
Ratio of Physicians to general population & $1: 1030$ & $1: 496$ \\
Number of Medical Schools in Canada & 8 & 17 \\
Total number of registered students & 1719 & 8,263 \\
\hline
\end{tabular}

${ }^{\dagger}$ Data from the Flexner report on Canadian Medical Schools ${ }^{1}$

One hundred years after the Flexner report, there are still ongoing issues regarding education delivery in North America. Understanding physician supply and demand continues to be a pressing but contentious issue. Since the Flexner report, there have been many attempts made to predict current and future physician demand in order to appropriately regulate supply. ${ }^{8}$ Though there have been committees made and papers written to understand this 
topic, it is still a controversial issue. Specifically, there is still debate as to whether a physician shortage or a surplus will affect us in the future, and if there is a shortage, whether that shortage will affect generalists, specialists, or both. ${ }^{9}$ ${ }_{10}$ This debate continues due to the complexity of predicting the future. Some experts try to predict future physician needs by examining the past. Others try to make estimations based on models of the future by examining variables that are difficult to predict, including economic growth, population expansion, physician effort, and the type and quantity of care provided by non-physician clinicians. ${ }^{10}$ These predictions are further complicated by exponential technological growth and a lack of understanding of the future role of physicians as new treatments and new diseases evolve. ${ }^{8}$

In keeping with Flexner's ideals, medical education is constantly being revised and revamped to adapt to the current needs of our society. Currently, policy changes in medical education in North America are being made from our best understanding of the past, present, and future supply and role of physicians in an evolving work environment. The effects of decision making in health care carry great weight, given the long lag period between educational reform and changes seen in practicing physicians. North America will have to continue to closely monitor trends in health supply and demand in order to adapt accurately to fluctuations in health care needs. We will have to continue employing technology like video conferencing and power point lectures to reduce lag times between advances in practice and teaching. ${ }^{11}$

The Flexner report was profoundly influential, and inspired a turning point in the history of medical education. ${ }^{12-13}$ It helped scientific medicine proliferate as the foundation of our current medical system. In the last century since his report was written, modern medicine and advances in society have allowed our species to effectively double its life expectancy.

Modern medicine continues to evolve, and new technologies and new diseases will continue to confront us with new challenges. As these challenges arise, it will be important for further assessments to be made regarding how to best educate and distribute our health care workforce. ${ }^{14}$ Flexner's mantras are as relevant today as they were at the beginning of the 1900's, and by ensuring high quality and standardization of medical education and licensing processes we can continue provide a high level of health care for the next 100 years to come. ${ }^{15-16}$

\section{References}

1. Flexner A. Medical education in the United States and
Canada. New York, NY: Carnegie Foundation for the Advancement of Teaching; 1910.

2. Beck A. The Flexner report and the standardization of American medical education. JAMA. 2004;291:2139-2140.

3. Bonner TN. Iconoclast. Abraham Flexner and a life of learning. Baltimore: The John Hopkins University Press; 2002.

4. Hunt S. The Flexner Report and black academic medicine: an assignment of place. J Natl Med Assoc. 1993;85:151-5.

5. Kwong JC, Dhalla IA, Streiner DL, Baddour RE, Waddell AE, Johnson IL. A comparison of Canadian medical students from rural and non rural backgrounds. Can J Rural Med. 2005;10:36-42.

6. Dhalla IA, Kwong JC, Streiner DL, Baddour RE, Waddell AE, Johnson IL. Characteristics of first year students in Canadian medical schools. CMAJ. 2002;166:1029-35.

7. Kwong JC, Dhalla IA, Streiner DL, Baddour RE, Waddell AE, Johnson IL. Effects of rising tuition fees on medical school class composition and financial outlook. CMAJ. 2002;166:1023-8.

8. Sheldon GF. Great expectations: the $21^{\text {st }}$ century health workforce. Am J Surg. 2003;185:35-41.

9. Blumenthal D. New steam from an old cauldron-the physician supply debate. New Engl J Med. 2004;350:1780-7. 10. Cooper RA, Getzen TE, McKee HJ, Laud P. Economic and demographic trends signal an impending physician shortage. Health Aff. 2002;21:140-54.

11. Baranchuk A, Dagnone G, Fowler P, Harrison MN, Redfearn DP, Simpson CS. Education at distance: broadcasting ECG rounds to Southeastern Ontario (BESO Project). An innovative approach for teaching electrocardiography. Clin Invest Med. 2007;30 (suppl. 4):51-52.

12. Busing N, Slade S, Rosenfield J, Gold I, Maskill S. In the spirit of Flexner: working toward a collective vision for the future of medical education in Canada. Acad Med. 2010;85:340-8.

13. Ludmerer K. Learning to Heal: The development of American medical education. Baltimore: The John Hopkins University Press; 1996.

14. Scheffler RM. Is there a doctor in the house? Market signals and tomorrow' supply of doctors. Palo Alto, CA: Stanford University Press; 2008.

15. Sullivan LW, Suez Mittman I. The state of diversity in the health professions a century after Flexner. Acad Med. 2010;85:246-53.

16. Ludmerer K. Understanding the Flexner report. Acad Med. 2010;85: 193-196. 